\title{
BNIP3 wt Allele
}

National Cancer Institute

\section{Source}

National Cancer Institute. BNIP3 wt Allele. NCI Thesaurus. Code C120109.

Human BNIP3 wild-type allele is located in the vicinity of 10q26.3 and is approximately 14 $\mathrm{kb}$ in length. This allele, which encodes BCL2/adenovirus E1B $19 \mathrm{kDa}$ protein-interacting protein 3 , is involved in the positive regulation of both autophagy and apoptosis. 